\title{
Compatibility of two predator species for biological control of the two-spotted spider mite
}

\author{
Morgana Maria Fonseca ${ }^{1}$ - Angelo Pallini ${ }^{1}$ - Pedro Hermano Marques ${ }^{1}$. Eraldo Lima ${ }^{1}$. \\ Arne Janssen ${ }^{1,2}$ D
}

Received: 22 October 2019 / Accepted: 9 December 2019 / Published online: 6 February 2020

(c) The Author(s) 2020

\begin{abstract}
Because predators may interfere with each other, an important step towards the implementation of successful release of multiple predators in biocontrol programs requires resolving how predators respond to the presence of heterospecific competitors. Several species of predatory mites are important biocontrol agents and the species Phytoseiulus macropilis and Neoseiulus californicus are used to control the two-spotted spider mite, Tetranychus urticae, an important pest in agriculture worldwide. We investigated their compatibility showing that the two predators do not avoid plants on which the other species is present together with their common prey, and demonstrated that their oviposition rates are not affected by the presence of the other species. However, the distribution of the eggs on leaf discs was affected by the presence of the heterospecific predator. This behaviour might weaken possible interference between these two biocontrol agents, which, in turn, may enable their persistence on plants and favour pest suppression. The increased joint use of several natural enemies for biological control highlights the importance of studies on predator-predator interactions.
\end{abstract}

Keywords Interspecific competition · Volatile chemical cues $\cdot$ Phytoseiidae $\cdot$ Augmentative biological control $\cdot$ Multiple predators

Arne Janssen

arne.janssen@uva.nl

Morgana Maria Fonseca

morganamaria.fonseca@gmail.com

Angelo Pallini

pallini@ufv.br

Pedro Hermano Marques

pdrohermano@gmail.com

Eraldo Lima

eraldo.lima@ufv.br

1 Department of Entomology, Federal University of Viçosa, Viçosa, Minas Gerais, Brazil

2 Evolutionary and Population Biology, IBED, University of Amsterdam, Science Park 904, 1098 XH Amsterdam, The Netherlands 


\section{Introduction}

The rising concern that the intensive use of pesticides leads to the development of pest resistance and has negative effects on human health and the environment has led to a strong growth in use of biological pest control approaches (Matson et al. 1997; Margni et al. 2002; UN Human Rights Council 2017; Wyckhuys et al. 2019). Amongst the strategies used, augmentative biological control consists of the seasonal release of large numbers of natural enemies to suppress population outbreaks of the target pest species (Hajek 2004; van Lenteren et al. 2018). This approach often involves the release of several natural enemies which may have complementary effects on controlling the pest species (Sih et al. 1998; Cardinale et al. 2003; Straub and Snyder 2008; Messelink and Janssen 2014). The presence of multiple natural enemies can give rise to several types of interactions that further increase food web complexity (Janssen et al. 1998; Sih et al. 1998; Messelink et al. 2012). For instance, two predators sharing the same prey may interfere with each other through competition or intraguild predation and the possible effects of such interactions have been increasingly considered in the design of effective biological control programs (Rosenheim et al. 1995; Janssen et al. 2006; Messelink et al. 2012; van Lenteren et al. 2018). However, alternative food sources, often present in crops, can mitigate such effects and allow competing predators to coexist long enough to complement each other in the control of pests (Messelink et al. 2013; Messelink and Janssen 2014).

When competing for resources, the success of individual predators depends more on their behavioural strategies than on their physical strength (Milinski and Parker 1991). The distribution of predators over prey patches is expected to be directly influenced by the availability of resources; however, the presence of competitors on these patches may also affect their foraging decisions (Janssen et al. 1997; Gnanvossou et al. 2003; Choh et al. 2010; Maleknia et al. 2013). If predators are not able to detect and avoid the presence of heterospecifics in prey patches, they might interact through the joint use of the resources and this may lower the foraging success of one of the competing species (Pianka 1974; Milinski and Parker 1991). In attempting to prevent such antagonistic effects, predators could avoid the presence of each other, leading to temporal or spatial segregation of their niches (Pianka 1974) and this could affect their efficacy of controlling herbivore populations. Here, we investigated the occurrence of such avoidance of competitors when predators are searching for patches with food.

Predatory mites (Acari: Phytoseiidae) are used as biological control agents in many agricultural systems, particularly to control species of phytophagous mites and small insects (van Lenteren et al. 2018). The predators from this family are the main natural enemies of the two-spotted spider mite, Tetranychus urticae Koch (Acari: Tetranychidae), one of the most polyphagous pests known: it attacks over 1100 plant species and is able to rapidly develop pesticide resistance (Van Leeuwen et al. 2010; Migeon and Dorkeld 2015). Two of these predatory mite species, Phytoseiulus macropilis (Banks) and Neoseiulus californicus (McGregor) (Acari: Phytoseiidae), are mass-produced and marketed for the control of the two-spotted spider mite in the Neotropics. Phytoseiulus macropilis is considered a specialist predator of Tetranychus species (McMurtry and Croft 1997; Oliveira et al. 2007) and N. californicus has a broader diet, feeding on various pest species and types of pollen (Croft et al. 1998; Gerson et al. 2003). The combined use of these predators is considered as control strategy because whereas $P$. macropilis tends to disperse when the density of spider mites is low, $N$. californicus remains behind because it can feed on other food sources and is more resistant to starvation (Vacacela Ajila et al. 2019). Besides being investigated for 
combined releases, both $P$. macropilis and $N$. californicus co-occur naturally in extensive regions of Brazil on various crops and on spontaneous vegetation (Ferla et al. 2007; Roggia et al. 2009). Therefore, these two predators potentially compete for spider mites and may be involved in more complex interactions such as intraguild predation (Fonseca et al. 2018).

Predatory mites are blind and chemical cues play a central role in their foraging behaviour (Sabelis and van de Baan 1983; van Wijk et al. 2008). Although it is known that both P. macropilis (Oliveira et al. 2009; Fadini et al. 2010) and N. californicus (Janssen et al. 1990) are attracted to volatiles from prey patches, it has not yet been reported how these predators respond to volatiles emanating from prey patches invaded by the other predator species. Moreover, we showed before that these predators have the potential to engage in intraguild predation (Fonseca et al. 2018). In such interactions, one predator may induce antipredator behaviour in the heterospecific competitor, such as avoiding its presence (Magalhães et al. 2005; van der Hammen et al. 2010) and shifting the distribution and oviposition in response to cues of the other species (Choh et al. 2010). These behavioural responses might affect community structure (Wissinger and McGrady 1993; Snyder and Wise 1999), and thus the performance of interacting predators in biological control programs.

Therefore, exploring how potentially interacting predators respond to the presence of each other is an important step towards successful release of multiple natural enemies. Here, our goal was to investigate this phenomenon between the predatory mites P. macropilis and $N$. californicus at three spatial scales. We first tested whether these predators avoided the volatiles of plants with their shared prey and the other predator species from a distance using a Y-tube olfactometer (Janssen et al. 1999b; Gnanvossou et al. 2003; Çakmak et al. 2006). Subsequently, we verified whether the predators avoided visiting and remaining on plants with the other predator. Lastly, we investigated the oviposition of the two predators in the presence and absence of the other species.

\section{Materials and methods}

\section{Plant material}

Jack bean plants (Canavalia ensiformis (L.) DC; Sementes Caiçara ${ }^{\circledR}$, Brazil) were grown from seeds in plastic pots $(2 \mathrm{~L})$ filled with commercial potting soil (Mecplant ${ }^{\circledR}$, Brazil) in a greenhouse $\left(25 \pm 7{ }^{\circ} \mathrm{C}, 70 \pm 20 \%\right.$ relative humidity $)$. Plants were watered twice a day and did not receive fertilizers or pesticides. Two-week-old plants with two fully developed leaves (about $20 \mathrm{~cm}$ high) were used for the rearing of spider mites and experiments.

\section{Mite cultures}

The two-spotted spider mite was reared on jack bean plants in a climate-controlled room $\left(25 \pm 3{ }^{\circ} \mathrm{C}, 70-90 \%\right.$ relative humidity and a photoperiod of 12:12 L:D). Uninfested jack bean plants were added to the spider mite culture twice per week. The predatory mites $P$. macropilis and $N$. californicus were reared under the same conditions as above on detached bean leaves infested with two-spotted spider mites. These leaves were put in a plastic tray $(1 \times \mathrm{w} \times \mathrm{h}=45 \times 30 \times 8 \mathrm{~cm})$ that was placed inside a second, water-containing tray $(55 \times 40 \times 10 \mathrm{~cm})$ to prevent the mites from escaping. New bean leaves with spider 
mites were added to the cultures $2-3 \times$ per week. The cultures of spider mites and predatory mites were started with individuals obtained from a commercial company (Ecotrix Biodefensivos Pesquisa \& Consultoria, Viçosa, MG, Brazil). Both predatory mite species had been reared for about 2 years on jack bean leaves with two-spotted spider mites prior to the experiments.

\section{Response of predatory mites to volatiles from heterospecifics}

To assess the response of adult female predatory mites to volatiles from heterospecific competitors, two-choice tests were done in a Y-tube olfactometer (Sabelis and van de Baan 1983; Janssen et al. 1999b). The olfactometer consisted of a Y-shaped glass tube $(27 \mathrm{~cm}$ long $\times 3.5 \mathrm{~cm}$ diameter) with a black Y-shaped metal wire in the middle to guide the predator, with the base of the tube connected to a pump that causes an airflow from the arms of the tube to the base (Janssen et al. 1999b). Each arm was connected to a glass container $(50 \times 36 \times 43 \mathrm{~cm})$ in which the volatile sources were kept. The wind speed in each arm of the $\mathrm{Y}$ tube was measured with a hot-wire anemometer and calibrated to $0.50 \mathrm{~m} / \mathrm{s}$ (VelociCalc® Air Velocity Meter 9545-A). When wind speeds in both arms are equal, the air flows coming from the containers form two separate fields in the base of the Y-tube, with the interface coinciding with the metal wire (Sabelis and van de Baan 1983).

Prior to the experiments, mated adult females of the predatory mites were taken from the culture and starved for 1-3 h, because this motivates the predators to walk upwind in the olfactometer (Sabelis and van der Weel 1993). The predatory mites were introduced individually in the olfactometer and each female was allowed to make a choice by reaching the end of one of the two arms within $5 \mathrm{~min}$. Females that did not make a choice within $5 \mathrm{~min}$ were scored as having made no choice. After making a choice or after $5 \mathrm{~min}$, the female was removed and a new female was introduced. Each replicate consisted of 20 adult females responding to a set of volatile sources plus a few non-responding females (0-3 per replicate). To correct for any possible unforeseen asymmetry in the experimental setup, volatile sources were connected to the opposite arm of the olfactometer after each five females that had made a choice. Three replicates were done per combination of volatile sources, each with a new set of plants and a new group of predators.

Each volatile source consisted of two jack bean plants that were infested with spider mites (T. urticae). Heterospecific predators were present on one group of plants and absent on the other group. The plants were infested with 300 adult females of T. urticae per leaf and they were subsequently incubated in this way for 2 days. This resulted in some visual damage, but plants were far from being overexploited. After this, one of two densities of the predatory mites was placed on one group of plants: 20 or 40 adult females per leaf, hence 40 or 80 per plant. Subsequently, plants were incubated for 2 more days. Plants were incubated in a climate room (conditions as above) until they were used for olfactometer experiments (conditions as above).

We first confirmed that both predator species were capable of performing well in the olfactometer by offering them a choice between the volatiles of clean and spider-miteinfested jack bean plants in an unreplicated test. Both predators were significantly attracted to volatiles of plants infested with spider mites (P. macropilis: 19 females to the infested plants and 1 to the clean plant, binomial test (Siegel and Castellan 1988), $\mathrm{P}<0.001 ; N$. californicus, 15 vs. 5, $\mathrm{P}=0.021$ ). Subsequently, we tested the response of the predators with plants harbouring prey plus adults of the other species. The choice offered was two jack bean plants infested with spider mites vs. two jack bean plants infested with spider mites 
plus the heterospecific predatory mite; this was repeated for both predator species and with both densities of predators on the plants.

The data of each two-choice olfactometer experiment were analysed with a log-linear model for contingency tables with Generalized Linear Model (GLM) using a Poisson error distribution (Crawley 2013). We first tested whether there was a preference for one of the arms of the olfactometer, which would point at an asymmetry in the set-up. We found no evidence for this (GLM, all $\chi^{2}<2.42$, d.f. $=1$, all $\left.\mathrm{P}>0.42\right)$. We subsequently assessed whether the choice of the predators differed significantly among replicates by constructing a GLM with volatile source, replicate and their interaction as fixed factors. A significant interaction between volatile source and replicate would point at an inconsistent preference of predators among replicates. All statistical analyses were done using R software (R Core Team 2016).

\section{Plant choice of predatory mites in presence of heterospecifics}

We tested the preference of adult females of the predatory mites P. macropilis and N. californicus between plants with and without heterospecific competitors. The jack bean plants had two fully developed leaves, of which one was infested with 150 adult females of $T$. urticae whereas the other leaf was kept clean. The plants were subsequently incubated in this way for 2 days. After this, 10 adult female predatory mites were placed on the preyinfested leaf of one group of plants, whereas the other group did not receive any predators. Subsequently, plants were incubated for 2 more days.

One satin ribbon (Merita ${ }^{\circledR}, 0.5 \mathrm{~cm}$ thick) was used to make a bridge between the plant with only prey (T. urticae) and the plant with prey plus predators. Another ribbon was tied to the centre of this bridge, the other end of this ribbon was vertically fixed with a paperclip onto one Petri dish (5 cm diameter, $1 \mathrm{~cm}$ deep) below the bridge, in between the two plants (Zhang et al. 2019). Subsequently, 50 adult female predatory mites of the species not present on the plants were randomly collected from the culture and were placed in two 1.5-mL Eppendorf safe-lock tubes. Subsequently, these Eppendorf tubes were placed in the Petri dish and the predatory mites were released, so that they could walk up the vertical ribbon to the bridge, and from there to the two plants, one with only spider-mite prey and the other with spider mites and predators of the other species. One day later the predators on both plants were counted.

Twelve pairs of plants were used for each species of predator. They were divided over three blocks in time with $N$. californicus as the released species and two blocks with P. macropilis as the released species. Each pair of plants was placed in a separate tray $(55 \times 40 \times 10 \mathrm{~cm})$ and the position of plants with and without the heterospecific competitors was alternated among trays to correct for any possible influence of directionality in the response of the predatory mites (Zhang et al. 2019).

The numbers of predatory mites arriving on the plants with and without heterospecific competitors were compared with a linear mixed effects model (LME) with treatment as fixed factor and replicate as random factor.

\section{Oviposition behaviour of interacting predators}

Lastly, we investigated whether the oviposition of the predators was affected by the presence of heterospecifics on prey patches. The patches consisted of leaf discs ( $5 \mathrm{~cm}$ diameter) of jack bean plants that were cut around the midrib, which served to split the leaf in two 
sides. The leaf discs were put on water-saturated cotton wool in a Petri dish $(8 \mathrm{~cm}$ diameter, $1.5 \mathrm{~cm}$ deep). To obtain patches with spider mites, 25 adult females were trapped on one side of the disc by putting a moistened cotton wool barrier on top of the midrib; the other side of the disc was maintained clean. The females were allowed to oviposit and produce web for $48 \mathrm{~h}$. After this, the cotton barrier was removed and the predators to be tested were released at the same time on the leaf discs, where they could feed on the spider mites and could oviposit either in the web produced by the spider mites or on the clean side of the leaf disc without web. All predators used here were gravid females, aged between 10 and 15 days since the egg stage.

Each leaf disc received one of three treatments: (i) T. urticae plus 1 individual of one of the predator species, (ii) T. urticae plus 3 individuals of the other predator species, and (iii) T. urticae, 1 individual of one of the predators and 3 individuals of the other predator. This last treatment mimicked the invasion of one individual of one species into a patch where three individuals of the other species was present. These three treatments were repeated with both predator species with one individual responding to the presence of three individuals of the other species. Each treatment was replicated $12 \times$. The eggs of the predatory mites were counted on each side of the disc after 24 and $48 \mathrm{~h}$.

The oviposition of predatory mites on each side of the leaf discs in the presence or absence of a higher density of the other species was compared using a GLM with a binomial error distribution (Crawley 2013). We assessed whether the distribution and total numbers of the eggs changed with the presence of the heterospecific competitor.

\section{Results}

\section{Response of predatory mites to volatiles from heterospecifics}

Phytoseiulus macropilis did not show a preference when offered a choice between volatiles of plants with spider mites and those of plants with spider mites plus $N$. californicus, both with a density of $20\left(\mathrm{GLM}, \chi^{2}=1.67, \mathrm{P}=0.20\right)$ or 40 heterospecific predators per leaf $\left(\chi^{2}=0.60, \mathrm{P}=0.44\right.$, both d.f. $=1$; Fig. 1$)$. There was no significant effect of the density of heterospecific predators on the plant $\left(\chi^{2}=2.14\right.$, d.f. $\left.=1, \mathrm{P}=0.14\right)$.

Neoseiulus californicus also did not show a preference for volatiles of plants with spider mites or those of plants with spider mites plus $P$. macropilis in both experiments with 20 (GLM, $\left.\chi^{2}=0.07, \mathrm{P}=0.80\right)$ or $40\left(\chi^{2}=2.42, \mathrm{P}=0.12\right.$, both d.f. $=1$; Fig. 2 ) heterospecific predators per leaf. There was no significant effect of the density of $P$. macropilis on the plants $\left(\chi^{2}=0.85\right.$, d.f. $\left.=1, \mathrm{P}=0.36\right)$.

There was no significant difference in preference among replicates for either of the species and densities (interaction between volatile source and replicate, all $\mathrm{P}>0.05$ ), showing that the lack of preference was consistent. We conclude that, despite the potential for competition and possible intraguild predation between individuals of the two predatory mite species (Fonseca et al. 2018), they do not avoid plants on which heterospecifics are present based on volatiles emanating from such plants.

\section{Plant choice of predatory mites in presence of heterospecifics}

Phytoseiulus macropilis had no significant preference for plants with spider mites or plants with spider mites plus $N$. californicus (LME, $\chi^{2}=0.38$, d.f. $=1, \mathrm{P}=0.54$; Fig. 3 ). 


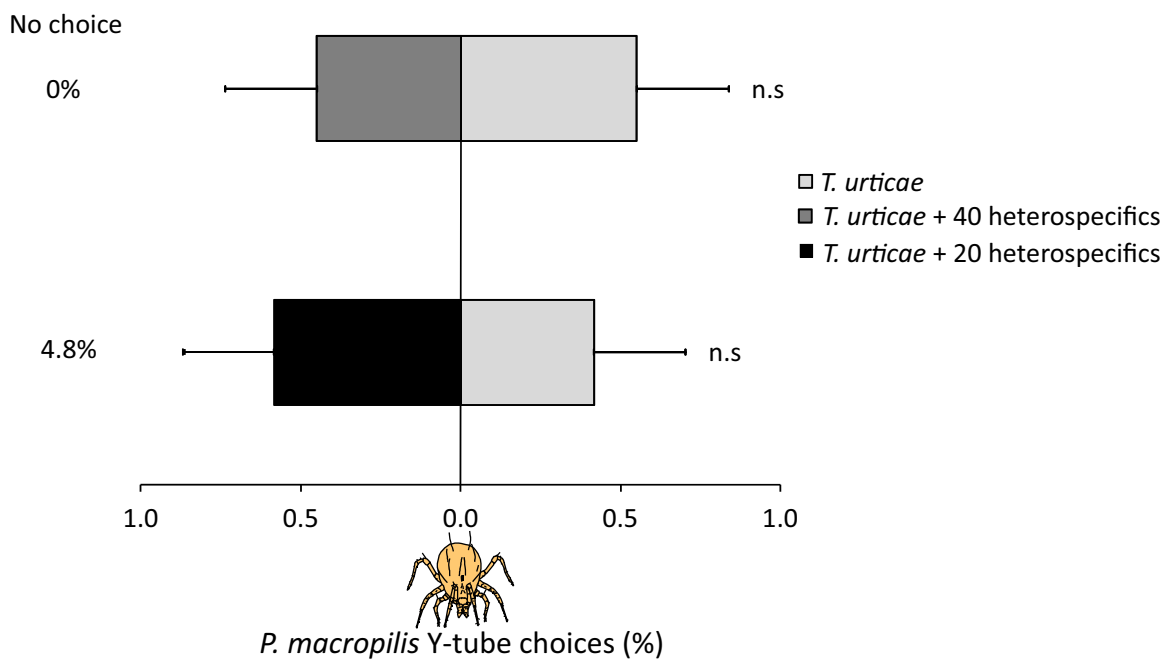

Fig. 1 The response of Phytoseiulus macropilis in an olfactometer when offered the choice between volatiles from plants with spider mites (right-hand side of the bars) and plants with spider mites and 20 or 40 Neoseiulus californicus per leaf (black and dark grey bars, respectively; left-hand side). Each bar is the average of three independent replicates with 20 predators making a choice in each replicate

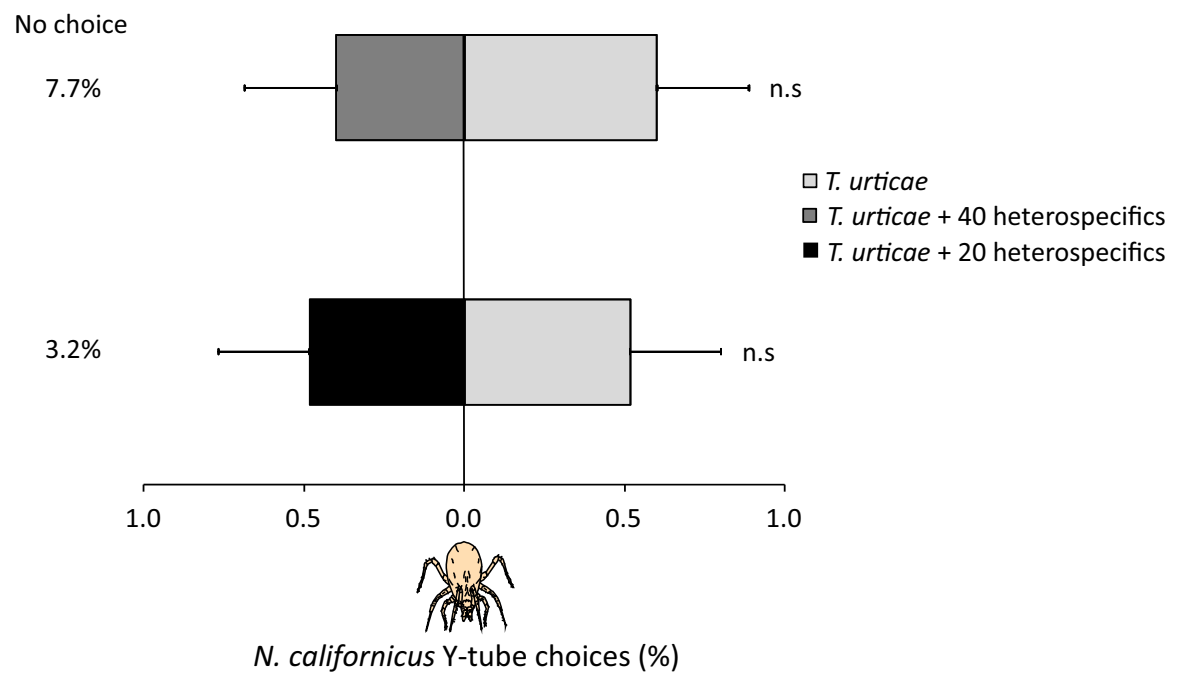

Fig. 2 The response of Neoseiulus californicus in an olfactometer to plants with spider mites (right-hand side of the bars) and plants with spider mites and 20 or 40 Phytoseiulus macropilis per leaf (black and dark grey bars, respectively; left-hand side). See Fig. 1 for further explanation

Neoseiulus californicus also did not show a significant preference for plants with spider mites compared to plants with spider mites plus $P$. macropilis $\left(\chi^{2}=0.87\right.$, d.f. $=1, \mathrm{P}=0.35$; Fig. 3). These results reinforce the findings from the olfactometer experiment: the predatory mites $P$. macropilis and $N$. californicus do not avoid plants on which heterospecifics are present. 

T. urticae + heterospecifics
$\square$ T. urticae

No choice

$7.2 \%$

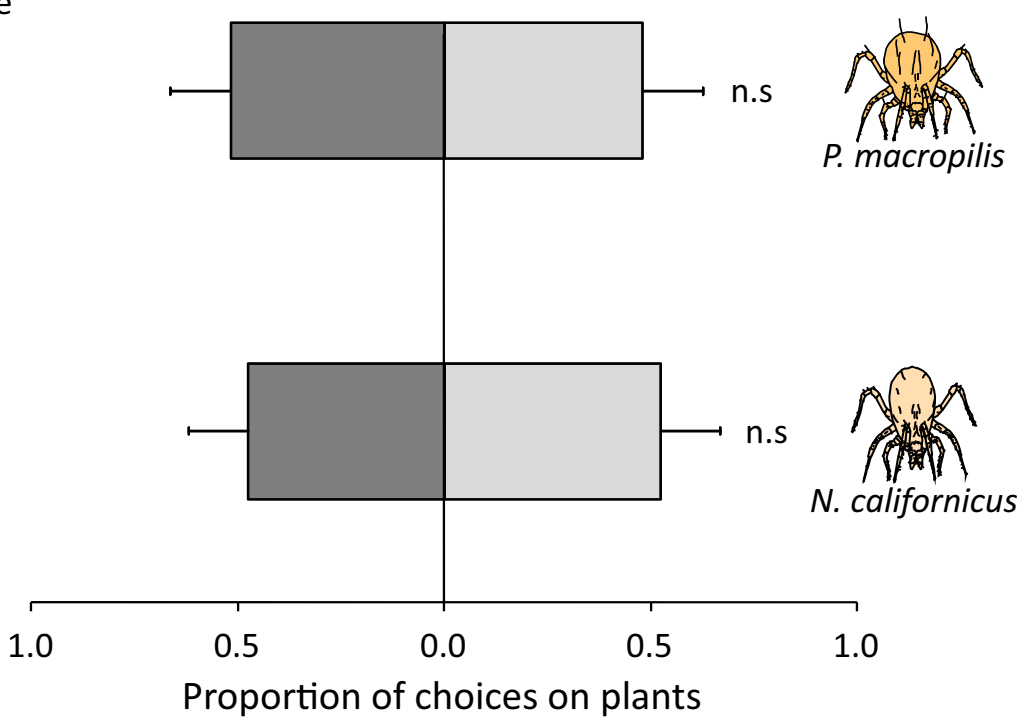

Fig. 3 The response of Neoseiulus californicus and Phytoseiulus macropilis to plants with spider mites (right-hand side of the bars) and plants with spider mites plus the heterospecific competitor (left-hand side). Bars are averages of 12 replicates

\section{Oviposition behaviour of interacting predators}

Both predatory mites changed the distribution of their eggs in the presence of a higher density of the other species. In these treatments, both $P$. macropilis (GLM, $\chi^{2}=8.55, \mathrm{P}=0.04$; Fig. 4) and $N$. californicus $\left(\chi^{2}=8.38, \mathrm{P}=0.004\right.$, both d.f. $=1$; Fig. 5) increased their oviposition on the clean side. However, the total number of eggs produced was not affected by the presence of the heterospecific for P. macropilis (GLM, $\chi^{2}<0.001$, d.f. $=1, \mathrm{P}=1$ ) or for $N$. californicus $\left(\chi^{2}=0.55\right.$, d.f. $\left.=1, \mathrm{P}=0.46\right)$. Therefore, whereas the egg distribution of both predators over the two sides of the leaf discs was affected by the presence of heterospecifics, their reproduction was not.

\section{Discussion}

Our results demonstrate that whereas both $P$. macropilis and $N$. californicus were significantly attracted to volatiles of jack bean plants infested with spider mites, neither of the two predator species avoided volatiles from plants with prey and heterospecifics, both with 20 or 40 predators per leaf. These results are in agreement with results with a closely related system of predatory mites, Phytoseiulus persimilis Athias-Henriot and N. californicus, which also showed that these predators do not avoid volatiles of plants with prey and the heterospecific species (Çakmak et al. 2006). Furthermore, it was demonstrated in greenhouse release experiments that $P$. persimilis did not avoid visiting plants with spider 


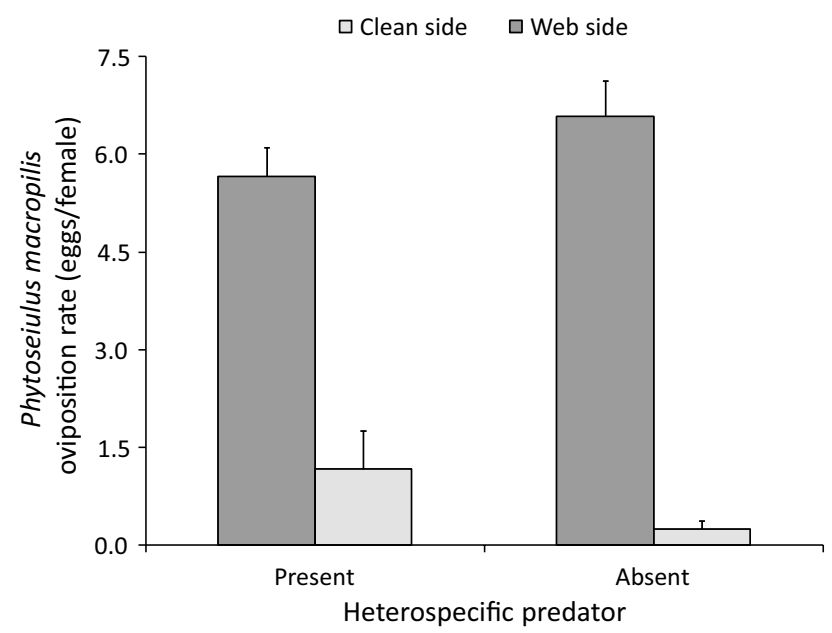

Fig. 4 Oviposition rates of Phytoseiulus macropilis in the presence (left-hand bars) or absence (right-hand bars) of Neoseiulus californicus and the distribution of the eggs over the webbed and clean sides of the leaf disc

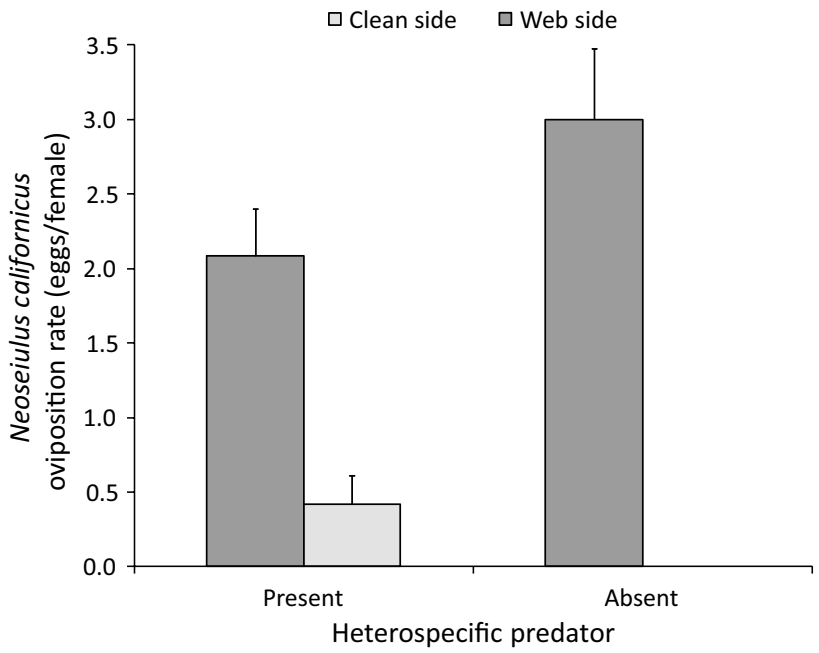

Fig. 5 Oviposition rates of Neoseiulus californicus in the presence (left-hand bars) or absence (right-hand bars) of Phytoseiulus macropilis and the distribution of the eggs over the two sides of the leaf disc

mites and $N$. californicus (Janssen et al. 1999b). Here, we also show absence of avoidance of competitors and potential intraguild predators for both P. macropilis and N. californicus, both in olfactometer and in release-recapture experiments. In contrast, other studies have shown avoidance of plants with con- or heterospecific competitors and intraguild predators based on volatiles emanating from these plants, both for predators (Janssen et al. 1997; Gnanvossou et al. 2003; Magalhães et al. 2005; Maleknia et al. 2013) and herbivores (Pallini et al. 1997). Because of the limited attention given to such interactions, the 
mechanisms of such volatile-mediated responses to conspecific or heterospecific predators are not yet well understood (Janssen et al. 1997; Chailleux et al. 2014).

Although P. macropilis and N. californicus have been found to co-occur naturally in Brazil (Ferla et al. 2007; Roggia et al. 2009), they may not have shared sufficient evolutionary history to result in selection for avoidance of plants with the other species. Another conceivable explanation for the lack of avoidance found in our system is that the predators used in our experiments did not have previous experience with heterospecifics. It is known that individual foragers have the ability to learn from previous foraging experiences (Bernstein et al. 1988, 1991), and it has been shown that predatory mites can change their response to volatiles after a negative experience (Dicke et al. 1990; Takabayashi and Dicke 1992; Drukker et al. 2000; De Boer and Dicke 2004). In parasitoids, selection pressures due to competitive interactions may drive the evolution of avoidance mediated by volatiles cues (Vet 1999). As our predator-predator system has the potential for competition and intraguild predation (Fonseca et al. 2018), their response to each other could be expected to change after experiencing such antagonistic interactions. This needs further investigation.

Theoretical models predict that possibilities for coexistence of species involved in intraguild predation are limited (Holt and Polis 1997), and that intraguild predation between natural enemies may have negative effects on biological pest control (Rosenheim et al. 1995). However, such negative effects on biological control seem to be an exception rather than the rule (Janssen et al. 2006). This is possibly caused by various factors such as habitat structure (Janssen et al. 2007), spatial niche partitioning (Finke and Denno 2006), and alternative food (Daugherty et al. 2007; Holt and Huxel 2007; Gagnon and Brodeur 2014), which can decrease the strength of this interaction and thus, the possible negative effects for biological control (Messelink and Janssen 2014). Our findings show that, although the presence of $P$. macropilis and $N$. californicus did not affect the reproduction of either species, the distribution of their eggs changed. In the absence of the heterospecific competitor, the two predators oviposited almost exclusively in the web produced by the prey, but when the other predator species was present, a higher proportion of eggs was laid outside this web. This indicates that, although the predatory mites have the same preference for oviposition sites, they changed their oviposition behaviour, possibly in attempting to avoid competition or intraguild predation and this flexibility may promote their persistence on an individual host plant.

The co-occurrence of the two competing predators on groups of plants might be facilitated by differences in their foraging behaviour. Neoseiulus californicus can feed on alternative food resources and it is much more resistant to starvation than the specialist $P$. macropilis. In another study, we showed that, whereas $62 \%$ of $P$. macropilis protonymphs had died on the 3rd day without food, $67 \%$ of $N$. californicus protonymphs were still alive 1 day later (Fonseca et al. 2018). Furthermore, P. macropilis has the tendency to disperse from crops when the density of the two-spotted spider mite is low, whereas $N$. californicus stays longer (Vacacela Ajila et al. 2019). This suggests that the two species have different ways of coping with ephemeral prey patches, and this may facilitate their coexistence (Nee and May 1992).

Despite the potential for interference between $P$. macropilis and $N$. californicus, our results suggest that they do not avoid each other. Future research should ascertain how these predatory mites affect each other's dynamics, as well as their subsequent effects on behaviour and population dynamics of the two-spotted spider mite, their shared prey. The increased joint use of several species of natural enemies for biological control highlights the importance of studying interactions within the third trophic level. Foraging behaviour, habitat selection and the spatial distribution of species determine the occurrence and 
strength of interactions within food webs (Abrams 1996; Janssen et al. 1999a). Therefore, a first step to understanding the dynamics of interacting biological control agents requires investigation of their foraging behaviour. Because volatile cues are essential for foraging predatory mites, olfactometer experiments are a good starting point for such investigations. The next step would be to explore their behaviour when the interacting species are present on the same plant. The mechanisms involved in such interactions can be determined at the smaller scale of experimental arenas. Although such studies may have important implications for ecological interactions and evolutionary processes, they are still limited to a small number of species and deserve more attention.

Acknowledgements We thank Ecotrix Biodefensivos Pesquisa \& Consultoria Ltda for support with the rearing of arthropods and the colleagues from the Laboratory of Acarology of the Federal University of Viçosa for suggestions on experimental design and discussions. We thank two anonymous reviewers for constructive comments. We also thank the Brazilian research funding agencies Coordination for the Improvement of Higher Education Personnel (CAPES), Foundation for Research Support of the State of Minas Gerais (FAPEMIG) and National Council of Scientific and Technological Development (CNPq). MMF was supported by Postdoc Grants (Process 88887.145883/2017-00 and 88887.314241/2019-00) from CAPES, AP by FAPEMIG and CNPq, EL by the National Institute of Science and Technology Semiochemicals in Agriculture (INCT/CNPq).

Author contributions AJ and MMF conceived the ideas and designed the methodology; MMF and PHM collected the data, AJ and MMF analysed the data; MMF and AJ led the writing of the manuscript. All authors contributed critically to the drafts and gave final approval for publication.

\section{Compliance with ethical standards}

Conflict of interest The authors declare that they have no conflict of interest.

Ethical approval The experiments comply with the current laws of the country in which the experiments were performed.

Open Access This article is licensed under a Creative Commons Attribution 4.0 International License, which permits use, sharing, adaptation, distribution and reproduction in any medium or format, as long as you give appropriate credit to the original author(s) and the source, provide a link to the Creative Commons licence, and indicate if changes were made. The images or other third party material in this article are included in the article's Creative Commons licence, unless indicated otherwise in a credit line to the material. If material is not included in the article's Creative Commons licence and your intended use is not permitted by statutory regulation or exceeds the permitted use, you will need to obtain permission directly from the copyright holder. To view a copy of this licence, visit http://creativecommons.org/licenses/by/4.0/.

\section{References}

Abrams PA (1996) Dynamics and interactions in food webs with adaptive foragers. In: Polis GA, Winemiller KO (eds) Food webs: integration of patterns and dynamics. Springer, Boston, pp 113-121

Bernstein C, Kacelnik A, Krebs JR (1988) Individual decisions and the distribution of predators in a patchy environment. J Anim Ecol 57:1007-1026

Bernstein C, Kacelnik A, Krebs JR (1991) Individual decisions and the distribution of predators in a patchy environment. II. The influence of travel costs and structure of the environment. J Anim Ecol 60:205-225

Çakmak I, Janssen A, Sabelis MW (2006) Intraguild interactions between the predatory mites Neoseiulus californicus and Phytoseiulus persimilis. Exp Appl Acarol 38:33-46. https://doi.org/10.1007/s1049 3-005-6247-7 
Cardinale BJ, Harvey CT, Gross K, Ives AR (2003) Biodiversity and biocontrol: emergent impacts of a multi-enemy assemblage on pest suppression and crop yield in an agroecosystem. Ecol Lett 6:857-865

Chailleux A, Wajnberg E, Zhou Y et al (2014) New parasitoid-predator associations: female parasitoids do not avoid competition with generalist predators when sharing invasive prey. Naturwissenschaften 101:1075-1083. https://doi.org/10.1007/s00114-014-1246-3

Choh Y, van der Hammen T, Sabelis MW, Janssen A (2010) Cues of intraguild predators affect the distribution of intraguild prey. Oecologia 163:335-340. https://doi.org/10.1007/s00442-010-1605-5

Crawley MJ (2013) The R book. Wiley, London

Croft BA, Monetti LN, Pratt PD (1998) Comparative life histories and predation types: are Neoseiulus californicus and N. fallacis (Acari: Phytoseiidae) similar type II selective predators of spider mites? Environ Entomol 27:531-538. https://doi.org/10.1093/ee/27.3.531

Daugherty MP, Harmon JP, Briggs CJ (2007) Trophic supplements to intraguild predation. Oikos 116:662-677. https://doi.org/10.1111/j.0030-1299.2007.15378.x

De Boer JG, Dicke M (2004) The role of methyl salicylate in prey searching behavior of the predatory mite $P h y$ toseiulus persimilis. J Chem Ecol 30:255-271

Dicke M, van der Maas KJ, Takabayashi J, Vet L (1990) Learning affects response to volatile allelochemicals by predatory mites. Proc Sect Exp Appl Entomol Neth Entomol Soc 1:35-36

Drukker B, Bruin J, Jacobs G et al (2000) How predatory mites learn to cope with variability in volatile plant signals in the environment of their herbivorous prey. Exp Appl Acarol 24:881-895

Fadini MA, Venzon M, Oliveira H et al (2010) Response of the predatory mite Phytoseiulus macropilis (Banks) to volatiles produced by strawberry plants in response to attack by Tetranychid mites (Acari: Phytoseiidae: Tetranychidae). Neotrop Entomol 39:248-252

Ferla NJ, Marchetti MM, Gonçalves D (2007) Ácaros predadores (Acari) associados à cultura do morango (Fragaria sp., Rosaceae) e plantas próximas no Estado do Rio Grande do Sul. Biota Neotrop 7:1-8

Finke DL, Denno RF (2006) Spatial refuge from intraguild predation: implications for prey suppression and trophic cascades. Oecologia 149:265-275

Fonseca MM, Pallini A, Lima E, Janssen A (2018) Ontogenetic stage-specific reciprocal intraguild predation. Oecologia 188:743-751. https://doi.org/10.1007/s00442-018-4256-6

Gagnon A-亡̀, Brodeur J (2014) Impact of plant architecture and extraguild prey density on intraguild predation in an agroecosystem. Entomol Exp Appl 152:165-173. https://doi.org/10.1111/eea.12213

Gerson U, Smiley R, Ochoa R (2003) Mites (Acari) for pest control. Blackwell Science, Malden

Gnanvossou D, Hanna R, Dicke M (2003) Infochemical-mediated intraguild interactions among three predatory mites on cassava plants. Oecologia 135:84-90

Hajek AE (2004) Natural enemies: an introduction to biological control. Cambridge University Press, Cambridge

Holt RD, Huxel GR (2007) Alternative prey and the dynamics of intraguild predation: theoretical perspectives. Ecology 88:2706-2712

Holt RD, Polis GA (1997) A theoretical framework for intraguild predation. Am Nat 149:745-764

Janssen A, Hofker C, Braun A et al (1990) Preselecting predatory mites for biological control: the use of an olfactometer. Bull Entomol Res 80:177-181

Janssen A, Bruin J, Jacobs G et al (1997) Predators use volatiles to avoid prey patches with conspecifics. J Anim Ecol 66:223-232

Janssen A, Pallini A, Venzon M, Sabelis MW (1998) Behaviour and indirect interactions in food webs of plantinhabiting arthropods. Exp Appl Acarol 22:497-521

Janssen A, Pallini A, Venzon M, Sabelis MW (1999a) Absence of odour-mediated avoidance of heterospecific competitors by the predatory mite Phytoseiulus persimilis. Entomol Exp Appl 92:73-82

Janssen A, Pallini A, Venzon M, Sabelis MW (1999b) Behaviour and indirect interactions in food webs of plant-inhabiting arthropods. In: Bruin J, van der Geest LPS, Sabelis MW (eds) Ecology and Evolution of the Acari. Springer, Dordrecht, pp 231-249

Janssen A, Montserrat M, HilleRisLambers R et al (2006) Intraguild predation usually does not disrupt biological control. In: Brodeur J, Boivin G (eds) Trophic and guild in biological interactions control. Springer, Dordrecht, pp 21-44

Janssen A, Sabelis MW, Magalhães S et al (2007) Habitat structure affects intraguild predation. Ecology $88: 2713-2719$

Magalhães S, Tudorache C, Montserrat M et al (2005) Diet of intraguild predators affects antipredator behavior in intraguild prey. Behav Ecol 16:364-370

Maleknia B, Golpayegani AZ, Saboori A, Magalhães S (2013) Olfactory responses of Phytoseiulus persimilis to rose plants with or without prey or competitors. Acarologia 53:273-284

Margni M, Rossier D, Crettaz P, Jolliet O (2002) Life cycle impact assessment of pesticides on human health and ecosystems. Agric Ecosyst Environ 93:379-392 
Matson PA, Parton WJ, Power A, Swift M (1997) Agricultural intensification and ecosystem properties. Science 277:504-509

McMurtry J, Croft B (1997) Life-styles of phytoseiid mites and their roles in biological control. Annu Rev Entomol 42:291-321

Messelink GJ, Janssen A (2014) Increased control of thrips and aphids in greenhouses with two species of generalist predatory bugs involved in intraguild predation. Biol Control 79:1-7

Messelink GJ, Sabelis MW, Janssen A (2012) Generalist predators, food web complexities and biological pest control in greenhouse crops. In: Larramendy ML, Soloneski S (eds) Integrated pest management and pest control—current and future tactics. InTech, Rijeka, pp 191-214

Messelink GJ, Bloemhard CMJ, Sabelis MW, Janssen A (2013) Biological control of aphids in the presence of thrips and their enemies. Biocontrol 58:45-55. https://doi.org/10.1007/s10526-012-9462-2

Migeon A, Dorkeld F (2015) A comprehensive database for the tetranychidae: http://www.montpellier.inra.fr. Accessed 20 June 2017

Milinski M, Parker GA (1991) Competition for resources. Behav Ecol 3:137-168

Nee S, May RM (1992) Dynamics of metapopulations: habitat destruction and competitive coexistence. J Anim Ecol 61:37-40

Oliveira H, Janssen A, Pallini A et al (2007) A phytoseiid predator from the tropics as potential biological control agent for the spider mite Tetranychus urticae Koch (Acari: Tetranychidae). Biol Control 42:105-109. https://doi.org/10.1016/j.biocontrol.2007.04.011

Oliveira H, Fadini MAM, Venzon M et al (2009) Evaluation of the predatory mite Phytoseiulus macropilis (Acari: Phytoseiidae) as a biological control agent of the two-spotted spider mite on strawberry plants under greenhouse conditions. Exp Appl Acarol 47:275-283. https://doi.org/10.1007/s10493-008-9217-z

Pallini A, Janssen A, Sabelis MW (1997) Odour-mediated responses of phytophagous mites to conspecific and heterospecific competitors. Oecologia 110:179-185

Pianka ER (1974) Niche overlap and diffuse competition. Proc Natl Acad Sci USA 71:2141-2145

R Core Team (2016) R: a language and environment for statistical computing. R Foundation for Statistical Computing, Vienna

Roggia S, Guedes JVC, Kuss-Roggia RCR et al (2009) Ácaros predadores e o fungo Neozygites floridana associados a tetraniquídeos em soja no Rio Grande do Sul. Pesq Agropecu Bras 44:107-110

Rosenheim JA, Kaya HK, Ehler LE et al (1995) Intraguild predation among biological-control agents: theory and evidence. Biol Control 5:303-335. https://doi.org/10.1006/bcon.1995.1038

Sabelis M, van de Baan H (1983) Location of distant spider mite colonies by phytoseiid predators: demonstration of specific kairomones emitted by Tetranychus urticae and Panonychus ulmi. Entomol Exp Appl 33:303-314

Sabelis M, van der Weel J (1993) Anemotactic responses of the predatory mite, Phytoseiulus persimilis AthiasHenriot, and their role in prey finding. Exp Appl Acarol 17:521-529

Siegel S, Castellan NJ (1988) Nonparametric statistics for the behavioral sciences, 2nd edn. McGraw-Hill, New York

Sih A, Englund G, Wooster D (1998) Emergent impacts of multiple predators on prey. Trends Ecol Evol 13:350-355

Snyder WE, Wise DH (1999) Predator interference and the establishment of generalist predator populations for biocontrol. Biol Control 15:283-292

Straub CS, Snyder WE (2008) Increasing enemy biodiversity strengthens herbivore suppression on two plant species. Ecology 89:1605-1615

Takabayashi J, Dicke M (1992) Response of predatory mites with different rearing histories to volatiles of uninfested plants. Entomol Exp Appl 64:187-193

UN Human Rights Council (2017) Report of the Special Rapporteur on the right to food. United Nations, New York

Vacacela Ajila HE, Colares F, Lemos F et al (2019) Supplementary food for Neoseiulus californicus boosts biological control of Tetranychus urticae on strawberry. Pest Manag Sci 75:1986-1992

van der Hammen T, de Roos AM, Sabelis MW, Janssen A (2010) Order of invasion affects the spatial distribution of a reciprocal intraguild predator. Oecologia 163:79-89. https://doi.org/10.1007/s00442-010-1575-7

Van Leeuwen T, Vontas J, Tsagkarakou A et al (2010) Acaricide resistance mechanisms in the two-spotted spider mite Tetranychus urticae and other important Acari: a review. Insect Biochem Mol Biol 40:563-572. https://doi.org/10.1016/j.ibmb.2010.05.008

van Lenteren JC, Bolckmans K, Köhl J et al (2018) Biological control using invertebrates and microorganisms: plenty of new opportunities. Biocontrol 63:39-59. https://doi.org/10.1007/s10526-017-9801-4

van Wijk M, De Bruijn PJA, Sabelis MW (2008) Predatory mite attraction to herbivore-induced plant odors is not a consequence of attraction to individual herbivore-induced plant volatiles. J Chem Ecol 34:791-803. https://doi.org/10.1007/s10886-008-9492-5 
Vet LE (1999) From chemical to population ecology: infochemical use in an evolutionary context. J Chem Ecol 25:31-49

Wissinger S, McGrady J (1993) Intraguild predation and competition between larval dragonflies: direct and indirect effects on shared prey. Ecology 74:207-218

Wyckhuys KA, Pozsgai G, Lovei GL et al (2019) Global disparity in public awareness of the biological control potential of invertebrates. Sci Total Environ 660:799-806

Zhang NX, van Wieringen D, Messelink GJ, Janssen A (2019) Herbivores avoid host plants previously exposed to their omnivorous predator Macrolophus pygmaeus. J Pest Sci 92:737-745

Publisher's Note Springer Nature remains neutral with regard to jurisdictional claims in published maps and institutional affiliations. 